\title{
Talajok víztartó képességét becslő módszerek
}

\section{Bevezetés}

A talaj vízháztartásától függ a természetes vegetáció és a termesztett növények vízellátása. Szerepet játszik a talaj levegő- és hőháztartásának, a biológiai aktivitás mértékének és a tápanyagforgalomnak a kialakításában is. Befolyásolja a talaj szerkezeti és technológiai tulajdonságait, meghatározza a talajmüvelés idejét, módját, valamint hat a talaj pufferképességére (VÁRALLYAY, 2004; 2005a,b).

A talaj vízháztartását meghatározó tulajdonságok egyike a talaj víztartó képessége, mely lehetővé teszi, hogy a talajba szivárgó víz akár hosszabb ideig is raktározódjon a talajban. A talaj víztartó képességének mérése költséges, munka- és időigényes. Ugyanakkor lehetőség van arra, hogy egyszerübben mérhető talajtulajdonságok alapján becsléssel határozzuk meg. A talajtani kutatások során kapott becslő függvényeket pedotranszfer függvényeknek (ptf) hívják a szakirodalomban. A meghatározást az angol „pedotransfer function”-ból vették át, mely a LAMP és KNEIB (1981) által használt „pedofunction” és a BOUMA és VAN LANENtől (1987) származó „transfer function” fogalmakból alakult ki. A pedotranszfer függvény definícióját BouMA (1989) fogalmazta meg először, miszerint a függvény segítségével a rendelkezésre álló információkból olyan adatokat lehet előállítani, amelyek elsődleges mért forrásból nem hozzáférhetőek. A ptf-ek többségét a talaj vízgazdálkodási tulajdonságainak becslésére dolgozták ki, de léteznek a talaj egyéb fizikai és kémiai jellemzőit számító módszerek is. RAWLS (1983) például a talajok térfogattömegére dolgozott ki becslö módszert; a talajok szerves folyadék visszatartó képességét MAKÓ (2002) pedotranszfer függvénnyel becsülte; UNO és munkatársai (2005) távérzékelt információkból becsülték a talajok szervesanyagtartalmát; BELL és VAN KEULEN (1995, cit: MINASNY, 2007) a talajok kationkicserélö képességének becslésére dolgoztak ki módszert. A hiányzó adatokat egyre gyakrabban helyettesítik becsült értékkel a talajtani kutatásban. A mezőgazdasági és a környezeti modellezéshez szükséges hiányzó adatok pótlására azok pedotranszfer függvényekkel történő becslése megoldást jelenthet. Ugyanakkor mindig szem elött kell tartani, hogy a becsült értékek hibája ismereten, így azok csak közelítő jellegüek és felülvizsgálatuk elmaradhatatlan feladat.

A becslő módszerek alkalmazása nem új keletü, annak ellenére, hogy a ptf fogalma csak 1989 óta létezik. Már korábban is igény volt rá, hogy a nehezen mérhető talajtulajdonságokat egyéb, könnyebben meghatározható adatokból számítsák. VÁRALLYAY és munkatársai (1979) az 1970-es évekkel bezárólag, MINASNY (2007) pedig napjainkig tekinti át a becslő módszerek kidolgozásának történetét, felsorolva a föbb eredményeket. Az ő munkájukat is felhasználva tekintem át az első talajfizikai ptf-ek megalkotásától napjainkig terjedő időszak becslő módszereit. 
BRIGGS és MCLANE (1907) voltak valószínüleg az elsők, akik a mechanikai összetétel és szerves anyag alapján becsülték a ,talajnedvességi egyenértéket” (moisture equivalent): a talajkapillárisok által visszatartott egyensúlyi talajnedvességet, amit a minta 30 perces, tömegállandóságáig történő percenkénti 5000 fordulat (a gravitációs erő 3000-szerese) centrifugálásával értek el. Ez az érték a mai terminológia szerint közelítőleg a szántóföldi vízkapacitásnak felel meg.

Adatbázisuk 104 mintájának elemzése alapján a „talajnedvességi egyenérték” számítására az alábbi (1) egyenletet határozták meg:

$$
0,022 \mathrm{~A}+0,002 \mathrm{~B}+0,13 \mathrm{C}+0,622 \mathrm{D}+0,627 \mathrm{E}=\mathrm{M} \pm 3,1
$$

ahol: A: 2-0,25; B: 0,25-0,05; C: 0,05-0,005 és D: 0,005-0 mm-es frakció (\%); E: szerves anyag (\%); M: „talajnedvességi egyenérték”.

Már Briggs és McLane is felismerték, hogy a számítás pontosítható, ha az adatbázis hasonló tulajdonságokkal rendelkező talajait csoportosítják, illetve a nagyon eltérőeket külön veszik és így minden csoportra más egyenletet írnak fel. A csoportegyenletek becslési hibája az egész adatbázisra felírt általános érvényü egyenlethez képest a harmadára-kétharmadára csökkent. Az adatbázisukban szereplő norfolki és portsmouthi talajokat például az alábbi (2) egyenlettel jellemezték:

$$
0,04 \mathrm{C}+0,59 \mathrm{D}+0,53 \mathrm{E}=\mathrm{M} \pm 1,1
$$

ahol: C: 0,05-0,005 és D: 0,005-0 mm-es frakció (\%); E: szerves anyag (\%); M: „talajnedvességi egyenérték".

Hazai kutatók már az 1930-as évektől foglalkoztak a talaj vízgazdálkodását jellemző talajtulajdonságok számított, közelítő meghatározásával. A talaj higroszkópossági értéke és agyagtartalma közötti tapasztalati összefüggést KoTZMANN (1938, CIT: MADOS, 1939) (későbbi nevén MADOs) írta le először [(3) és (8) egyenletek], majd MADOs (1939), illetve KREYBIG (1951) a higroszkóposság, vízkapacitás és holtvíztartalom kapcsolatát vizsgálták [(4), (5), (6), (9) és (10) egyenletek].

MADOS (1939) a következő tapasztalati összefüggéseket írta le munkájában, melyben a talaj növényi vízellátásban kitüntetett víztartalmát tanulmányozta:

$$
\begin{aligned}
& \mathrm{A}=10,02 \text { hy }+5,02 \\
& \mathrm{VK}_{\text {term }}=4 \text { hy }+12 \\
& \mathrm{VK}_{\text {lab }}=5,6 \text { hy }+16,5 \\
& \mathrm{HV}_{\text {búza }}=4 \text { hy }+2
\end{aligned}
$$

ahol: A: agyagtartalom; hy: Kuron-féle higroszkóposság; $\mathrm{HV}_{\text {búza }}$ : búzára vonatkoztatott holtvíz érték; $\mathrm{T}_{\text {nedv }}$ : talajnedvesség; $\mathrm{VK}_{\mathrm{lab}}$ : Vageler szerint laboratóriumi talajmintán meghatározott víztartó képesség; $\mathrm{VK}_{\text {term }}$ : természetes viszonyok között meghatározott víztartó képesség.

MADOS $(1939,1942)$ a talajok kötöttsége és vízkapacitása közötti összefüggés vizsgálatának előzményeként Alten, Vageler, Kreybig, valamint Briggs és Schantz eredményeit említette.

ID. VÁRALLYAY (1942) a növények hervadáspontjához tartozó talajnedvességet, a légszáraz talaj nedvességének háromszorosával találta egyezőnek.

KREYBIG (1951) a „légszáraz talaj nedvességtartalma” - melyet „hy”-nal jelölt [Kreybig a Kuron-féle higroszkópossági értéket (hy) légszáraz nedvességtartalomnak nevezte] - és a talaj egyes fizikai és vízgazdálkodási tulajdonságai közötti összefüggéseket [(7)-(10) egyenletek] ismertette: 


$$
\begin{gathered}
\text { Hy }=2,2 \times \text { hy }( \pm 0,4) \\
\text { agyagtartalom }=10 \times \text { hy } \\
\text { „anyagi vízkapacitás" }=8 \times \text { hy } \\
\text { holtvíztartalom }=4 \times \text { hy }
\end{gathered}
$$

ahol: „anyagi vízkapacitás”: a minimális vízkapacitásnak felel meg a mai terminológia szerint; hy: Kuron-féle higroszkóposság, Hy: Mitscherlich-féle higroszkóposság.

Az összefüggések nem szikes és nem duzzadó agyagtalajokra vonatkoznak, részben figyelembe véve a talaj szervesanyag-tartalmát is. Kreybig módosítást javasolt a durvább fizikai féleségű talajok [azon talajok, ahol 10\%-nál kevesebb a 0,02 mm-nél kisebb méretű szemcsék részaránya (STEFANOVITS et al., 1999)] vízgazdálkodási tulajdonságainak számításához, miszerint ezen talajok minimális vízkapacitása a hy-érték hatszorosával egyenlö.

Az 1950-1980-as időszakban föként a talajok mechanikai összetételének, térfogattömegének és szervesanyag-tartalmának a víztartó képességre gyakorolt hatását vizsgálták a higroszkópos, a szántóföldi vízkapacitás és a holtvíztartalom nedvességértékeken. A 1950-es évek végén Nielsen és Shaw egyszerủ grafikus módszert dolgozott ki a talajok holtvíztartalmának számítására a homok-, iszap- és agyagtartalom alapján (VÁRALlYAY et al., 1979). Az 1960-as években egyre többen kezdték el vizsgálni a talaj szemcseeloszlása és víztartó képessége közötti összefüggést és foglalkoztak a víztartóképesség-értékek különböző függvényekkel való leírásával. Közülük kiemelkedő BROOKS és COREY (1964), SALTER és WILliAMS (1965, 1967), valamint BRUTSAERT (1966) munkássága. A következő évtizedben a talaj vízmozgásának modellezése, valamint a talajban lejátszódó transzportfolyamatok egzakt fizikai összefüggések megoldására alapozott leírása nagyot fejlődött. Megnőtt az igény a talaj vízgazdálkodási tulajdonságok értékeinek az ismeretére, mivel ezek elengedhetetlen input paraméterei a vízgazdálkodási modelleknek. Az 1980-as években hazánkban RAJKAI és munkatársai (1981) dolgoztak ki becslő módszert a pF-görbe értékeinek talajtulajdonságokból történő számítására. Vizsgálataik alapján megállapították, hogy a különböző tenziótartományokban $(\mathrm{pF} \leq 1 ; 1<\mathrm{pF} \leq 2,3 ; \mathrm{pF}>2,3)$ más-más talajtulajdonság mutat szignifikáns összefüggést a talaj víztartóképesség-értékkel. Az egyre több országban végzett talajvizsgálatok lehetővé tették a talajtulajdonságok közötti összefüggések vizsgálatát, és az általános érvényű pedotranszfer függvények kidolgozását (HALL et al., 1977; GUPTA \& LARSON, 1979; RAJKAI et al.,1981; RAWLS \& BRAKENSIEK, 1985).

Az utóbbi két évtizedben több olyan talaj-vizgazdálkodási és -fizikai adatbázist hoztak létre a világon, melyek alkalmasak pedotranszfer függvények kifejlesztésére. Ezek közül a legjelentősebbeket az 1. táblázatban mutatom be, kiemelve a mért vízpotenciál értékeket.

Napjainkra a talaj vízgazdálkodási tulajdonságait, ezen belül a talajok víztartó képességét becslö pedotranszfer függvények kidolgozása a talajtani kutatások egyik központi kérdésévé vált az egész világon.

\section{A becslési eljárásokban figyelembe vett talajtulajdonságok}

A legtöbb víztartó képesség becslő módszer - statisztikai szempontból folytonos valószínűségi változókként [a talajtulajdonságok, attól függően, hogy folytonosak, illetve diszkrétek, meghatározzák, hogy milyen becslő módszer alkalmazható] - a következő 


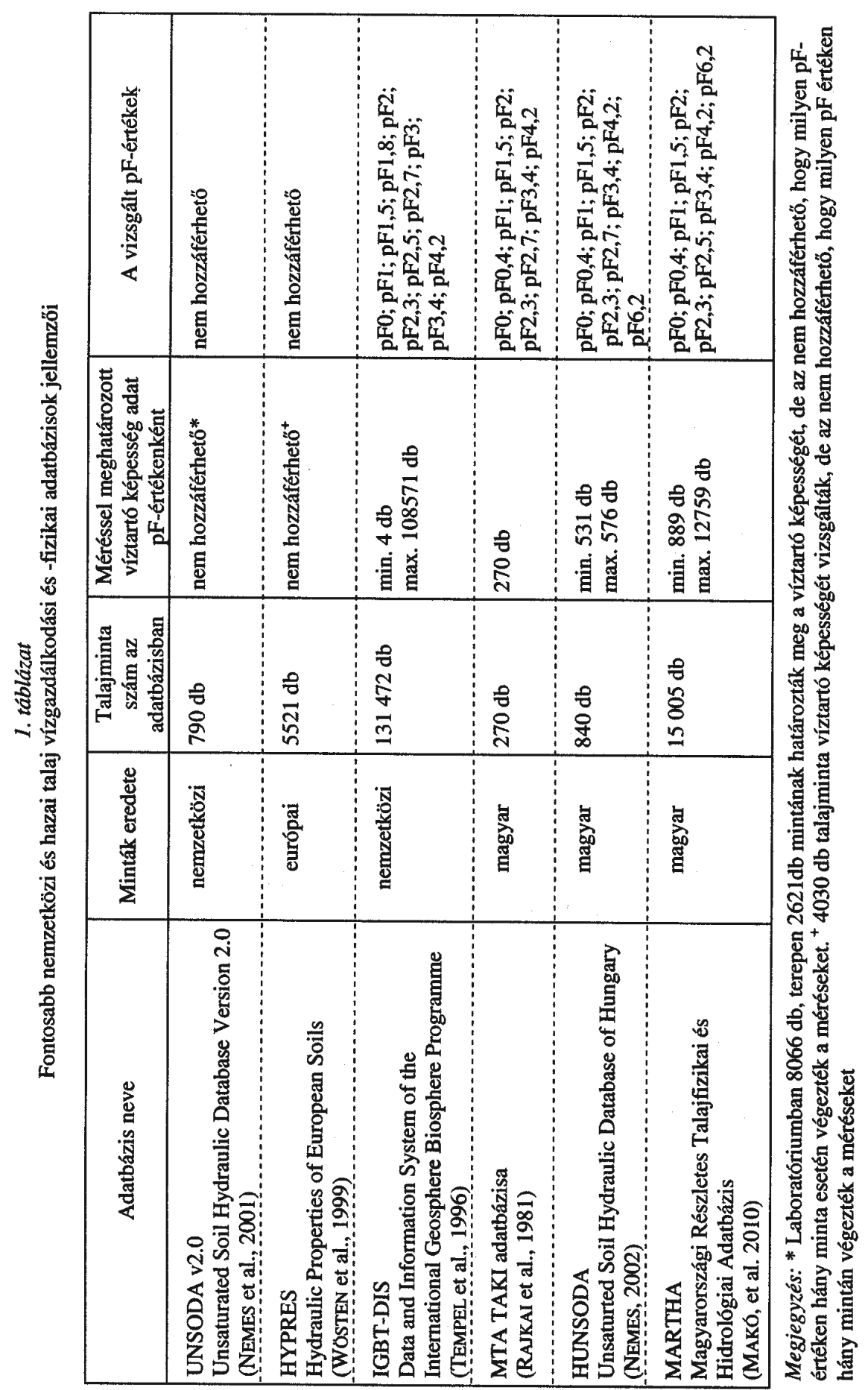


talajtulajdonságokat használja: a talajok mechanikai összetétele, szervesanyag-tartalma, térfogattömege (WÖSTEN et al., 2001; PACHEPSKY et al., 2006). A következőkben a becslö egyenletekben előforduló talajtulajdonságokat előfordulási gyakoriságuk alapján foglalom össze.

A mechanikai összetétel ismerete szinte az összes ptf-hez szükséges, mert a szemcsefrakciók fajlagos felülete határozza meg döntő mértékben a talaj vízkötő képességét. A különböző szemcsefrakciók hatása a talaj víztartó képességére pF-értékenként más és más. Általánosságban elmondható, hogy a $1,5 \leq \mathrm{pF} \leq 2,3$ szakaszban a finom homokfrakció $(0,25-0,05 \mathrm{~mm})$ a meghatározó, mert az e szemcsefrakciók között kialakuló kapilláris-gravitációs pórusrendszer ebben a tenziótartományban ürül le. A magasabb tenziótartományban $(\mathrm{pF}>2,3)$ a szorpciós erök hatása a döntö, így nagy adszorptív felülete miatt az agyagfrakció a meghatározó (RAJKAI et al., 1981; VÁRALLYAY, 2002; MAKÓ szóbeli közlés), aminek pozitív hatása van a talaj víztartó képességére. A mechanikai összetételt sokféleképpen alkalmazhatják a becslésekben. Egyes szerzők (PACHEPSKY et al., 1982; RAJKAI et al., 1981; WÖSTEN et al., 1999) a szemcsefrakció kategóriákat veszik alapul. [A szemcsefrakció határok országonként igen eltérőek (NEMES et al., 1999).] Vannak, akik bizonyos frakciók átmérőjének geometriai átlaga alapján (SCHEINOST et al., 1997; MINASNY et al., 1999), vagy a talaj homok-, por- és agyagfrakciójának, illetve ezek egymáshoz viszonyított arányának (például homok- és iszapfrakció aránya) figyelembe vételével számolnak (RAJKAI \& VÁRALLYAY, 1992; WÖSTEN et al., 1999).

A talaj szervesanyag-tartalmát is nagyon sok szerző bevonja a becslésbe (RAWLS et al., 1982, 1983, 2006, 2004; RAJKAI, 1988; WÖSTEN et al., 1999), föként annak térfogattömegre gyakorolt hatása miatt. A talaj szervesanyag-tartalma meghatározza a szerveskolloid-felület nagyságát (RAJKAI, 1988) és hatással van a talaj szerkezetére és adszorpciós tulajdonságaira is (RAWLS et al., 2003), így közvetlenül és közvetve is meghatározza a talaj víztartó képességét. RAWLS és munkatársai (2003) megállapította, hogy a szerves anyag mennyiségbeli változásának a talaj víztartó képességére gyakorolt hatása egyrészt a talaj szemcseösszetételétől, másrészt a talaj szervesanyag-tartalmának nagyságától függ. A durva fizikai féleségű talajok víztartó képessége érzékenyebb a szerves anyag mennyiségének változására, mint a finomabb szemcséjü talajoké. Továbbá kis szervesanyag-tartalom esetén, a talaj szervesanyag-tartalmának bizonyos szintig tartó növekedésével a durvább fizikai féleségü talajok víztartó képessége nő. Nagyobb szervesanyag-tartalomnál, a talaj szervesanyag-tartalmának növekedése, a talaj fizikai féleségétől függetlenül, nagyobb víztartó képességet eredményez (RAWLS et al., 2003).

A térfogattömeget több szerző is fontosnak találta (RAJKAI et al., 1981; RAWLS et al., 1982; WÖSTEN et al., 1999; BRUAND et al., 2003) és vette figyelembe a ptf kidolgozásában. A térfogattömeg jellemzi a mikro- és makroaggregátumok, valamint a nagyobb szerkezeti elemek illeszkedésének szorosságát, tehát a gravitációs pórusok mennyiségéröl ad tájékoztatást. Alacsony tenziótartományban $(\mathrm{pF} \leq 1)$ ezért fóként e talajtulajdonságok határozzák meg, hogy mennyi vizet tárol a talaj (RAJKAI et al., 1981; VÁRALLYAY, 2002; MAKÓ szóbeli közlés).

A fent említett talajtulajdonságokon kívül egyéb talajtulajdonságokat is be lehet vonni a talaj víztartó képességének becslésébe, ezeket a teljesség igénye nélkül, a szakirodalomban fellelhető munkák alapján a következőkben mutatom be.

Mért víztartóképesség-értékek becslésbe vételével a becslő modellek átlagos hibája és becslési hatékonysága szignifikánsan javult (RAWLS et al., 1982; AHUJA et al., 1985; 
RAJKAI, 2004). Legtöbbször a -33 kPa és $-1500 \mathrm{kPa}$ potenciálértékeken mért értékeket használják.

Egyéb fizikai tulajdonságok, melyek a talaj pórusterének nagyságát befolyásolják, szintén figyelembe vehetök (WÖSTEN et al., 2001), így:

- a talajellenállás;

- az agronómiai szerkezet, vagyis az aggregátumok méretéből adódó tulajdonság (STEFANOVITS et al., 1999);

- a szerkezet stabilitás, ami arról ad információt, hogy a kolloidok mekkora része van stabil kötésben (STEFANOVITS et al., 1999).

E talajtulajdonságoknak az alacsonyabb tenziótartományban van jelentőségük, ahol a kapilláris és a gravitációs potenciál befolyásolja a talaj víztartó képességét (VÁrAllyay, 2002).

Bizonyos kémiai tulajdonságok figyelembe vétele szintén fontos lehet, például a szikes talajok esetében, amint erre RAJKAI (1988) is rámutatott. Munkájában a szikesedés pF-értékekre gyakorolt hatását a talaj só-, oldható- és kicserélhető Na-ion tartalmával és karbonáttartalmával jellemezte. $\mathrm{A} \mathrm{CaCO}_{3}$-tartalom víztartó képességre gyakorolt szerepére RAJKAI és VÁRALLYAY (1992) hívta fel a figyelmet. Az említett kémiai tulajdonságokon kívül cementáló hatásuk miatt figyelembe vehetik még a talajban található vas-oxidok és vas-hidroxidok mennyiségét, vagy a talaj kationkicserélö képességét (WÖSTEN et al., 2001). A kis szervesanyag-tartalmú talajok esetén a kationkicserélö képesség alapján következtetni lehet az agyagásvány-összetételre (PACHEPSKY \& RAWLS, 2004).

Vannak olyan eljárások is, amelyek kategóriaváltozókat (diszkrét változókat), például a fizikai féleséget (BATJES, 1996; SCHAAP et al., 2001; BRUAND et al., 2003; MAKÓ et al., 2005; TÓTH et al., 2005), a talaj altípust (TÓTH et al., 2005; MAKÓ \& TóTH, 2007), a talaj taxonómiai osztályát (BATJES, 1996; RAWLS et al., 2003), a talajban található uralkodó agyagásvány-összetételt (WÖSTEN et al. 2001) veszik figyelembe. Más módszerek pedig kvalitatív tulajdonságokat vesznek be a becslésbe, például a talaj morfológiát. PACHEPSKY és munkatársai (2006) a talaj szerkezetét, WALCZAK és munkatársai (2006) a talaj porozitását, LIN és munkatársai (1999) a makropórusok méretét, típusát és előfordulásuk gyakoriságát, a gyökerek méretét, előfordulási gyakoriságát és a talaj szerkezetét használták fel a talaj víztartóképesség-becslésben. MCKENZIE és MACLEOD (1989) a talaj szinét vette figyelembe egyéb talajtulajdonságok mellett a szabadföldi vízkapacitás becslésében. Néhányan (BASTET, 1999; JAMAGNE et al., 1977 cit: PACHEPSKY \& RAWLS 2004) a talajképző közet alapján csoportosítják a talajokat, azon feltevés alapján, hogy a talajképző kőzet határozza meg elsődlegesen a talaj agyagásvány-összetételét.

A domborzatot jellemzö tulajdonságok vizsgálata is gyakran fellelhető (PACHEPSKY et al., 2001; SHARMA et al., 2006; SANTRA \& DAS, 2008) a ptf-kidolgozás gyakorlatában. ROMANO és PALLADINO (2002) például a lejtő alakját találták fontosnak a víztartó képesség becslésében.

A fent említett fizikai és kémiai talajtulajdonságokon kívül az irodalomban fellelhetők olyan módszerek is, amelyek például a talaj párologtatása alapján következtetnek a víztartó képességre (IDEN \& DURNER, 2008), vagy olyanok, amik a vegetációs indexet (NDVI, ami egy adott terület vegetációs aktivitását fejezi ki) (SHARMA et al., 2006) veszik figyelembe. 


\section{A talaj víztartó képességét becslő módszerek rendszerezése}

Mára nagyon sok víztartóképesség-becslő módszert dolgoztak ki és használnak a talajtanban. Érdemes ezért azokat rendszerezve áttekinteni, ahogy azt a külföldi szakirodalmakban - különböző szempontok szerint - már többen megtették (CORNELIS et al., 2001; WÖSTEN et al., 2001; MCBRATNEY et al., 2002; NEMES et al., 2003; PACHEPSKY \& RAWLS, 2004). A becslő módszerek áttekintéséhez az említett szakirodalmakra is támaszkodtam. A szerzők egyetértenek abban, hogy a becslö módszerek alapvetően két típusba sorolhatók. A fizikai modell alapú becslések csoportjába és az empirikus módszerek közé. Ez utóbbiba tartozik a pedotranszfer függvények többsége.

A fizikai modell alapú becslések (semiphysical approach/physical model method/ mechanistic model) abból a tényből indulnak ki, hogy a talajok szemcse- és pórusméret eloszlása között összefüggés van (ARYA \& PARIS, 1981). BROOKS és COREY (1964) megállapították, hogy a talaj pF-görbéje és szemcseeloszlás-görbéje hasonló lefutású. A szemcseeloszlást és a pF-görbét leíró függvény átlagos meredekségét jellemző paramétere között szignifikáns pozitív korreláció van (RAJKAI, 1988). Ezen a fizikailag is igazolható hasonlóságon alapszik a talajok pF-görbéjének a mechanikai összetételből történő számíthatósága (RAJKAI, 1988). A talaj víztartó képességét leíró görbékhez a fizikai folyamatok leírásával jutnak el (RAJKAI, 2004). A talajok szemcse-eloszlásából számítják a pórusméret-eloszlást, a pórusméret-eloszlásból becslik a nedvességtartalmat (TIETJE \& TAPKENHINRICHS, 1993). Ezt az eljárást alkamazták a munkájukban például HAVERKAMP és PARLANGE (1986), TYLER és WHEATCRAFT (1989), valamint COMEGNA és munkatársai (1998).

A másik nagy csoportba tartoznak az empirikus módszerek, melyek nem a fizikai elméletek sorából levezetett és egymásra épülő összefüggéseken alapulnak, hanem a becsléshez használt bemenő és kimenő paraméterek közötti összefüggéseket írják fel (ROSSITER, 2003).

\section{Pedotranszfer függvények}

A becslö módszerek többsége az ún. folytonos pedotranszfer függvény (continuous pedotransfer functions) típusba sorolható. A becslésbe vont talajtulajdonságok és a talaj víztartó képességét jellemző görbe paraméterei vagy a talaj adott vízpotenciálon mért víztartóképesség-értéke közötti kapcsolat folytonos matematikai függvénnyel írható le. A folytonos ptf-ekhez legtöbbször folytonos talajváltozókat alkalmaznak magyarázó változóként.

A csoportbecslö pedotranszfer függvények (class pedotransfer functions), fogalmat WÖSTEN és munkatársai (1990) határozták meg. Ezen ptf-ek kidolgozása elött, az adatbázis egy-egy talajmintára vonatkozó vízgazdálkodási és egyéb adatait felhasználva talajcsoportokat képeznek (PACHEPSKY \& RAWLS, 2004). A talajcsoportokat az átlagos vízgazdálkodási tulajdonságokkal jellemzik. A talajcsoportokra dolgoznak ki becslő függvényeket, a csoportban szignifikáns talajtulajdonságok meghatározásával. A hasonló talajokra kidolgozott pedotranszfer függvények becslési hibája általában kisebb, mint a teljes adatbázisra kidolgozottaké. A talajcsoportok kialakítása többféleképpen történhet. A módszerek többségében a fizikai féleség adja az osztályozás alapját (RAWLS et al., 1982; BRUAND et al., 2003; TÓTH et al., 2005; PACHEPSKY et al., 2006; BAKER, 2008; WÖSTEN et al., 1995). Csoportképző lehet még a talaj szervesanyag-tartalma 
(RAWLS et al., 2003), szerkezete (PACHEPSKY \& RAWLS, 2003), a talaj altípusa (TóTH et al., 2005; MAKÓ \& TÓTH, 2007), vagy taxonómiai kategóriája (BATJES, 1996; RAWLS et al., 2001), a feltalaj és az altalaj (WÖSTEN et al., 1990; RAWLS et al., 2001), vagy a talajképző kőzet (PACHEPSKY \& RAWLS, 2004). Természetesen a felsorolt lehetőségek kombinációja alapján is történhet a talajok osztályozása, többszintü talajcsoportok kialakításával (pl. RAWLS et al., 2003). A csoportbecslő ptf-ekhez kategóriaváltozók is használhatók.

Abban az estben, ha csak kategóriaváltozók (diszkrét változók) állnak rendelkezésre a becsléshez, inkább beszélünk pedotranszfer szabályok megalkotásáról, mint pedotranszfer függvényről. Ebben az esetben a becslés eredménye egy kategóriaérték.

\section{Pedotranszfer szabályok}

A pedotranszfer szabály (pedotransfer rule, ptr) kifejezés először BATJES (1996) munkájában jelenik meg. A talajok hasznosítható vízkészletét (diszponibilis vízkészletét, DV) becsülte a FAO-UNESCO által készített világ talajai atlaszán feltüntetett talajegységek (talajtípusok), fizikai féleség és szerves anyag kategóriák alapján. Először minden talajegységre számolt egy átlagos DV-t, majd azt rendelte a szabályoknak megfelelő tulajdonságokkal rendelkező azon talajmintákhoz is, amiknél nem álltak rendelkezésre mért víztartóképesség-adatok. Később ezt a szabályalkotó módszert talajosztályozás alapú szabálynak (taxotransfer rule) nevezték, mivel a szabályalkotás rendszertani egységenként különbözik. Nagy adatbázisok statisztikai eredményei alapján rendelik a szabályok alapján besorolt talajhoz a hiányzó tulajdonságokat (BATJES et al., 1997). E módszer kidolgozásának a feltétele tehát a kellően nagy adatbázis, hiszen minden talajegységnek reprezentatív mintaszámmal kell rendelkeznie (BATJES et al., 2007).

Pedotranszfer szabályokat több szerző is alkalmazott, például QUISENBERRY és munkatársai (1993), DAROUSSIN és KING (1996), LILLY és munkatársai (1996), valamint MAKÓ és munkatársai (2005). A pedotranszfer szabályokkal a kvalitatív talajtulajdonságok minőség fokozatuk alapján ordinális skálára konvertálhatók, így lehetővé téve e tulajdonságok használatát a statisztikai elemzésekben (LILLY et al., 1996). A talaj víztartó képességének ptr-ekkel történő becslését leginkább kontinentális vagy globális méretű alkalmazásokban használják. Ezekben a léptékekben az adatbázisok ugyanis kategória típusú adatokat tartalmaznak, így a becsült tulajdonságok kvalitatív jellegüek (DAROUSSIN \& KING, 1996; BATJES, 1996).

\section{A becslés típusai}

A becslö módszerek vagy a pF-görbe jellemző pontjaihoz tartozó víztartó képességet, vagy a pF-görbét leíró függvény paramétereit számítják.

Azon ptf-ek esetén, amelyek a talaj víztartó képességet meghatározott mátrix potenciálokon becslik (a pF-görbe mért pontjain) pontbecslésröl (point estimation methods) beszélünk. Ezt a módszert alkalmazták többek között GUPTA és LARSON (1979); RAJKAI és munkatársai (1981); RAWLS és BRAKENSIEK (1982); RAWLS és munkatársai (1982); AHUJA és munkatársai (1985); RAJKAI (1988); továbbá TOMASELLA és munkatársai (2003).

Görbebecslésnek (parametric estimation methods) nevezik azt az eljárást, amikor a víztartóképesség-görbét leíró függvény paraméterértékeit számítják egyéb talajtulajdon- 
ság értékekből. A függvényparaméterek alkalmazása a pF-görbe 10 mért értékét becslő tíz ptf helyett 3-5 függvényparamétert becslö ptf-el helyettesíthető (RAJKAI, 1988). Így például:

- többek között RAWLS és BRAKENSIEK (1985) valamint MAYR és JARVIS (1999) a BROOKS és COREY (1964) függvény (10) paramétereit becsülte:

$$
\theta=\theta_{\mathrm{r}}+\left(\theta_{\mathrm{s}}-\theta_{\mathrm{r}}\right) \cdot\left(\mathrm{h}_{\mathrm{A}} / \mathrm{h}\right)^{\lambda}
$$

ahol: $\theta$ : a talaj nedvességtartalma (tf \% vagy $\left.\mathrm{m}^{3} \times \mathrm{m}^{-3}\right)$; h: a talaj nedvességpotenciálja $(\mathrm{cm}) ; \theta_{\mathrm{r}}, \theta_{\mathrm{s}}$, $\mathrm{h}_{\mathrm{A}}, \lambda$ : illesztési paraméterek.

- VEREECKEN és munkatársai (1989), SchEINOST és munkatársai (1997), SCHAAP és munkatársai (1999), WÖSTEN és munkatársai (1999), RAJKAI (2004), valamint BØRGESEN és SCHAAP (2005) a VAN GENUCHTEN (1980) pF-függvényének paramétereit (11) számították:

$$
\theta(\mathrm{h})=\theta_{\mathrm{r}}+\left(\left(\theta_{\mathrm{s}}-\theta_{\mathrm{r}}\right) /\left(1+(\alpha \mathrm{h})^{\mathrm{n}}\right)^{\mathrm{m}}\right)
$$

ahol: $\theta$ : a talaj nedvességtartalma (tf $\%$ vagy $\left.\mathrm{m}^{3} \times \mathrm{m}^{-3}\right)$; h: a talaj nedvességpotenciálja $(\mathrm{cm}) ; \theta_{\mathrm{r}}, \theta_{\mathrm{s}}$, $\alpha, \mathrm{n}, \mathrm{m}$ : illesztési paraméterek.

- RAJKAI (2004), valamint TÓTH és munkatársai (2005) az alapvető talajtulajdonságok és a BRUTSAUERT (1966) függvény (12) paraméterei közötti összefüggéseket vizsgálták:

$$
\theta=\theta_{\mathrm{s}} /\left(\left(1+(\alpha \mathrm{h})^{\mathrm{n}}\right)\right.
$$

ahol: $\theta$ : a talaj nedvességtartalma $\left(\mathrm{tf} \%\right.$ vagy $\left.\mathrm{m}^{3} \times \mathrm{m}^{-3}\right)$; h: a talaj nedvességpotenciálja $(\mathrm{cm}) ; \theta_{\mathrm{s}}, \alpha$, $\mathrm{n}$ : illesztési paraméterek.

A van Genuchten-egyenletnek (12) van inflexiós pontja, ezért jobb az alkalmazhatósága, mint a Brooks és Corey modellnek, föként víztelített nedvességpotenciál közelében. Ezt használják ezért a legtöbbször a talaj víztartó képességének a leírására (CORNELIS et al., 2001). A Brutsaert-függvény előnye, hogy kisebb hibával illeszkedik a hazai talajokra, mint a van Genuchten-függvény. Hátránya viszont, hogy paraméterei nem adják meg a vízvezetőképesség-függvényét.

A pontbecslést főként akkor alkalmazzák, amikor a talaj teljes vízkapacitásának, szabadföldi vízkapacitásának és holtvíztartalmának ismeretére van szükség. Ha azonban a talaj víztartó képességét leíró pF-görbe meghatározása a cél, amire például a transzport modellekben van szükség, akkor görbebecslést alkalmaznak. Pontbecslés során a középső tenziótartományban $(2<\mathrm{pF} \leq 2,7)$ a legnagyobb a becslés hibája, mert ott a talajok nedvességtartalma különböző hatások eredőjeként alakul (RAJKAI, 1988). TóTH és munkatársai (2005) a pF0-érték nedvességtartalma becslésében kapta a legnagyobb hibát, amire az adhat magyarázatot, hogy e nedvességpotenciálon a víztartó képesség meghatározása alapadat szinten is bizonytalan.

\section{A becslésekben használt statisztikai módszerek}

A talaj víztartó képességének a becslését legtöbbször regressziós függvényekkel végzik, amelyek lehetnek többváltozós lineáris vagy nem-lineáris függvények.

A többváltozós lineáris regresszió (multiple linear regression) az egyváltozós lineáris regresszió kiterjesztése, amikor is több független változó és egy függő változó közöt- 
ti kapcsolatról van szó. A pontbecslő ptf-ekben használják leginkább ezt a technikát, de például a van Genuchten-függvény ((11) egyenlet) paramétereit is több szerző ezzel a módszerrel becsülte (VEREECKEN et al., 1989; SCHEINOST et al., 1997; MINASNY et al., 1999; WÖSTEN et al., 1999; RAJKAI et al., 2004).

Általában a következő egyenlettípussal jellemzik az adott mátrix potenciálhoz tartozó víztartó képességet (WÖSTEN et al., 2001):

$\theta_{\mathrm{h}}=\mathrm{a}$ homok $+\mathrm{b}$ iszap $+\mathrm{c}$ agyag $+\mathrm{d}$ szerves anyag $+\mathrm{e}$ térfogattömeg $+\ldots+\mathrm{x} \mathrm{X}$ váltózó

ahol: $\theta_{\mathrm{h}}$ : a talaj nedvességtartalma meghatározott h nedvességpotenciálon; a, b, c, d, e, x regreszsziós koefficiensek; az X változó pedig a könnyen mérhető talajtulajdonságok egyike.

RAJKAI (1988) a víztartóképesség és bizonyos talajtulajdonságok kapcsolatát négyzetes tagot is tartalmazó regressziós egyenlettel írta le, így csökkentve a becslés hibáját:

$$
\mathrm{pFx}=\mathrm{b}_{0}+\mathrm{b}_{1} \mathrm{x}_{1}+\mathrm{b}_{2} \mathrm{x}_{2}+\mathrm{b}_{3} \mathrm{x}_{1} \mathrm{x}_{2}+\mathrm{b}_{4} \mathrm{x}_{1}^{2}+\mathrm{b}_{5} \mathrm{x}_{2}^{2}
$$

ahol: $\mathrm{b}_{0}-\mathrm{b}_{5}$ : a regressziós együtthatók, $\mathrm{x}_{1}$ : az első helyen korrelatív független változó, $\mathrm{x}_{2}$ : a második helyen korrelatív független vátozó, $\mathrm{x}_{1}$ és $\mathrm{x}_{2}: \mathrm{pF}$-görbe ponttól függően lehet a talaj valamely szemcsefrakciója, térfogattömege vagy szervesanyag-tartalma.

A nem-lineáris regressziós egyenlet (extended non-linear regression) független változók csoportja és egy függő változó közötti nemlineáris kapcsolatok feltárására szolgál. Ezt az eljárást alkalmazták, például SCHEINOST és munkatársai (1997), valamint RAJKAI és munkatársai (2004).

Az 1990-es években új adatbányászati technikákat kezdtek alkalmazni a becslések kidolgozására, úgy, mint a mesterséges neurális hálózat, a csoportos adatkezelés módszere, vagy a klasszifikáció és regressziós fa együttes alkalmazása. A továbbiakban röviden bemutatom ezeket a módszereket és a 2. táblázatban összefoglalom alkalmazásuk előnyeit és hátrányait.

A mesterséges neurális hálózatok (artificial neural network (ANN)) módszere adott minták alapján akkor is elkészíti a bemenő és kimenő adatok közötti kapcsolatok modelljét, ha ez képlettel nem írható le, vagy a megoldáshoz szükséges szabályok ismeretlenek. Ahhoz, hogy a bemenő adatok és a kimenő értékek közötti kapcsolatot feltárjuk, a hálózatot először „tanítani” kell. A tanítás során az ismert bemenő adatokból a hálózat müködési eredményét ismert adatokhoz hasonlítják, és ha a mennyiségek eltérnek, úgy igazítják a hálózat müködését, hogy az illeszkedés hibája a lehető legkisebb legyen. A neurális hálózatok használata igen alkalmas sok összefüggő bemenő adat és összefüggő kimeneti paraméter esetén, ha az adathalmaz nem teljes, vagy hibás és/vagy, ha a megoldáshoz szükséges szabályok ismeretlenek (SÁRKÖZY, 1998; NEMES et al., 2003; BøRGESEN \& SCHAAP, 2005). Pedotranszfer függvények előállítására sokan alkalmazták már ezt a módszert (PACHEPSKY et al., 1996; SCHAAP \& LEIJ, 1998; MINASNY et al., 1999; SCHAAP et al., 1999; NEMES et al., 2003; BAKER \& ElLISON, 2008).

A csoportos adatkezelés módszere (group method of data handling (GMDH)) olyan módszer, amely több bemenő és egy kimenő változó közötti kapcsolatot tárja fel. A regressziós vizsgálat és a mesterséges neurális hálózatok elönyeit ötvözi. Egy flexibilis neurális hálózat típusú összefüggéssel jellemzi a bemenő és kimenő adatok közötti kapcsolatot, miközben csak a becsléshez fontos bemenő változókat tartja meg (GIMĖNEZ et al., 2001). Használata előnyös, ha sok a független változó a becslésben (PACHEPSKY \& RAWLS, 2004). 
2. táblázat

Újabb adatbányászati eljárások összevetése a hagyományos regressziós módszerekkel*

\begin{tabular}{|c|c|c|}
\hline & Előnyök & Hátrányok \\
\hline \multicolumn{3}{|c|}{ Mesterséges neurális hálózat } \\
\hline $\begin{array}{l}- \\
- \\
-\end{array}$ & $\begin{array}{l}\text { nem kíván előzetes ismeretet a bemenő } \\
\text { és kimenő változók kapcsolatáról; } \\
\text { kategóriaváltozókat is tud kezelni; } \\
\text { a változók közötti kapcsolat leírása } \\
\text { bármilyen egyenlettel lehetséges; } \\
\text { robusztus. }\end{array}$ & $\begin{array}{l}\text { _ } \quad \text { a becsléshez szükséges bemenő para- } \\
\text { métereket elözetesen kell kiválasztani; } \\
\text { _ } \quad \text { a bemenő és kimenő változók közötti } \\
\text { kapcsolatokat legtöbbször nem lehet ér- } \\
\text { telmezni, mert a modell bonyolult } \\
\text { egyenletekkel írja le azokat (black-box } \\
\text { model); } \\
\text { az iterációk száma nehezen optimali- } \\
\text { zálható. }\end{array}$ \\
\hline \multicolumn{3}{|c|}{ Csoportos adatkezelés módszere } \\
\hline- & $\begin{array}{l}\text { nagyszámú paraméterböl kiválasztja a } \\
\text { szignifikáns független változókat; } \\
\text { megadja a bemeneti és kimenő para- } \\
\text { méterek közötti egyenletek rendszerét. }\end{array}$ & $\begin{array}{l}\text { - } \quad \text { kategóriaváltozókat nem tud kezelni; } \\
\text { - } \quad \text { az iterációk száma nehezen optimali- } \\
\text { zálható. }\end{array}$ \\
\hline \multicolumn{3}{|c|}{ Klasszifikációs fa (regressziós fa) } \\
\hline $\begin{array}{l}- \\
- \\
-\end{array}$ & $\begin{array}{l}\text { az eredmények kiértékelése könnyebb; } \\
\text { kategóriaváltozókat is kezel; } \\
\text { nem normális eloszlású adatokra is } \\
\text { alkalmazható. }\end{array}$ & $\begin{array}{l}\text { - nehéz meghatározni a hierarchia szintek } \\
\text { és azok osztályainak optimális számát. }\end{array}$ \\
\hline
\end{tabular}

Megjegyzés: * GimÈnez et al. (2001), Nemes et al. (2003), PACHEPSKY \& RAwls (2004), és PACHEPSKY et al. (2006) alapján

A klasszifikációs fa (regressziós fa) (classification tree, regression tree, CART) használatakor elöször a sokaság elemeit az elemek tulajdonságai szerint két vagy több csoportba osztályozzák. Ezután a regressziós fa módszer az adatokat homogén alcsoportokra osztja. Ez a módszer alkalmas abban az esetben, ha input paraméterként kategóriaváltozókat használnak a becsléshez (RAWLS et al., 2003; PACHEPSKY et al., 2006).

\section{A pedotranszfer függvények alkalmazása és megbízhatóságának vizsgálata}

Általánosságban elmondható, hogy azon függvényekkel a leghatékonyabb a becslés, amelyeket a vizsgálandó terület talajaihoz hasonló tulajdonságú talajadatbázison dolgoztak ki (SCHAAP \& LEIJ, 1998). Minél specifikusabbak a ptf-függvények, annál pontosabb becslést adnak, de csupán kisebb területre, vagy meghatározott talajféleségre.

Annak eldöntésében, hogy a vizsgálandó adatbázisban és az alkalmazni kívánt ptf kalibrációs adatbázisában szereplő talajok tulajdonságai hasonlónak tekinthetők-e, a különböző statisztikai távolságszámítások segítenek (NEMES et al., 2006, TRANTER et al., 2009). A megfelelö ptf kiválasztásához TRANTER és munkatársai (2009) a következő eljárást javasolják: 
a) a ptf kalibrációs adatbázisának független változóira adjuk meg az átlagértékek és a szórások értékeit és vizsgáljuk meg a variancia-kovariancia mátrixukat;

b) határozzuk meg a kalibrációs adatbázis kiugró adatait és számítsuk ki a kiugró adatok távolságát az adatbázis számtani átlagától;

c) számítsuk ki a Mahalanobis távolságot a ptf kalibrációs adatbázisának számtani átlaga és a vizsgálandó talajminták között;

d) amennyiben $\mathrm{c}>\mathrm{b}$, ne használjuk a pedotranszfer függvényt.

A ptf-ek becslési hatékonyságát és adatigényét több szerző is (RAJKAI \& KABOS, 1999; Cornelis et al., 2001; Wösten et al., 2001; Børgesen \& SCHAAP, 2005; AL MAJOU et al., 2008) összehasonlította különböző adatbázisokon. Egyöntetű megállapításuk, hogy a becslőeljárások pontosságának alapja a kalibrációs adatbázis és becslő adatbázis tulajdonságainak hasonlósága. Minél specifikusabbak a pedotranszfer függvények, annál pontosabb becslést eredményeznek kisebb, homogénebb talajcsoportra. Ez a magyarországi becslési eljárások esetében is igaz, pl. a szikesek víztartó képességét becslő függvények érvényességét tekintve (RAJKAI, 1988). Országos léptékü hidrológiai számításokhoz viszont a nagyobb, heterogénebb talajmintákat tartalmazó adatbázison kidolgozott ptf-ek használhatóbbak (TóTH et al., 2005), amint azt hazai viszonyokra MAKó és munkatársai (2010a,b) a Magyarországi Részletes Talajfizikai és Hidrológiai Adatbázisra (MARTHA) vonatkozó munkája mutatja. A MARTHA adatbázis a különbözö hazai nem szikes és szikes talajokra specifikus ptf-függvények kidolgozására is lehetőséget nyújt (TÓTH et al., 2006; MAKÓ \& TÓTH, 2007; MAKÓ et al., 2010a,b). Országos léptékủ becslések kidolgozásához azonban a kontinentális léptékü adatbázis használata nem javasolt, mert az nagyobb becslési hibát eredményez (NEMES et al., 2003; MAKÓ et al., 2010a,b).

Amennyiben nem lelhető fel a szakirodalomban olyan talaj víztartó képességet számító ptf vagy ptr, ami alkalmazható lenne a saját adatainkra (például: nem áll rendelkezésre a modellhez szükséges bemenő paraméterek egyike - vagy annak becslése nem lehetséges, ill. nem célravezető) akkor merülhet fel egy létező ptf/ptr módosítása a hozzáférhető adatokra (MAKó et al., 2010a,b), vagy egy új ptf/ptr kidolgozása. A 3. táblázat néhány gyakran használt ptf adatigényét tartalmazza.

MCBRATNEY és munkatársai (2002) felhívják a figyelmet arra, hogy az új becslő modellek kidolgozásánál szükséges a kiugró adatok kiszürése a kalibrációs adatbázisból. A kidolgozott becslő modellek pontosságát (accuracy) a teszt (kalibrációs) adatbázison, megbizhatóságukat (reliability) a teszt adatbázistól független adatbázison kell ellenőrizni (WÖSTEN et al., 2001). A modellek e tulajdonságait legtöbbször az átlagos hiba (ME) ((16) egyenlet) és az átlagos négyzetes hiba négyzetgyöke (RMSE), más néven empirikus szórás ((17) egyenlet) adja meg.

$$
\begin{gathered}
M E=\frac{\sum_{1}^{N}\left(y_{i}-\hat{y}_{i}\right)}{N} \\
R M S E=\sqrt{\frac{\sum_{1}^{N}\left(y_{i}-\hat{y}_{i}\right)^{2}}{N}}
\end{gathered}
$$

ahol: $y_{i}:$ a mért érték; $\hat{y}_{i}:$ az y becsült érték; $\mathrm{N}$ : mintaelemszám. 
3. táblázat

Néhány talajvíztartó-képességet becslő pedotranszfer függvény adatigénye

\begin{tabular}{|c|c|c|c|}
\hline Becslés típusa & Szerzők & Bemenő paraméterek & $\begin{array}{l}\text { Becsült talajtulaj- } \\
\text { donságok }\end{array}$ \\
\hline \multirow{2}{*}{$\begin{array}{l}\text { Többváltozós lineá- } \\
\text { ris regresszió } \\
\text { Pontbecslés }\end{array}$} & $\begin{array}{l}\text { GUPTA \& } \\
\text { LARSON (1979) }\end{array}$ & $\begin{array}{l}0,002-0 ; 0,05-0,002 ; 2-0,05 \\
\text { mm-es szemcsefrakciók; szer- } \\
\text { ves anyag; térfogattömeg }\end{array}$ & $\begin{array}{l}\text { pF2; pF2,5; pF3; } \\
\text { pF4,2 }\end{array}$ \\
\hline & $\begin{array}{l}\text { RAJKAI et al. } \\
\text { (1981) }\end{array}$ & $\begin{array}{l}0,002-0 ; 0,005-0,002 ; 0,01- \\
0,005 ; 0,02-0,01 ; 0,05-0,02 \\
\text { mm-es szemcsefrakciók; térfo- } \\
\text { gattömeg }\end{array}$ & $\begin{array}{l}\text { pF0;pF0,4; pF1; } \\
\text { pF1,5;pF2; pF2,3; } \\
\text { pF2,7; pF3,4; } \\
\text { pF4,2; pF6,2 }\end{array}$ \\
\hline \multirow[t]{2}{*}{$\begin{array}{l}\text { Többváltozós lineá- } \\
\text { ris regresszió } \\
\text { Görbebecslés }\end{array}$} & $\begin{array}{l}\text { VEREECKEN et } \\
\text { al. (1989) }\end{array}$ & $\begin{array}{l}0,002-0 ; 0,01-0,002 ; 0,02- \\
0,01 ; 0,05-0,02 ; 0,1-0,05 ; 0,2- \\
0,1 ; 0,5-0,2 ; 1-0,5 ; 2-1 \mathrm{~mm}-\mathrm{es} \\
\text { szemcsefrakciók; szerves szén; } \\
\text { térfogattömeg }\end{array}$ & \multirow{4}{*}{$\begin{array}{l}\text { van Genuchten- } \\
\text { függvény négy } \\
\text { paramétere: } \Theta_{\mathrm{s}}, \Theta_{\mathrm{r}}, \\
\alpha, \mathrm{n}\end{array}$} \\
\hline & $\begin{array}{l}\text { SCHEINOST et al. } \\
\text { (1997) }\end{array}$ & $\begin{array}{l}0,002-0 ; 0,063-0,002 ; 2- \\
0,063 ; 63-2 \text { mm-es szemcse- } \\
\text { frakciók; szerves szén; térfo- } \\
\text { gattömeg }\end{array}$ & \\
\hline $\begin{array}{l}\text { Mesterséges } \\
\text { neurális hálózat } \\
\text { Görbebecslés }\end{array}$ & $\begin{array}{l}\text { SCHAAP \& LEIJ } \\
\text { (1998) }\end{array}$ & $\begin{array}{l}0,002-0 ; 0,05-0,002 ; 2-0,05 \\
\text { mm-es szemcsefrakciók; térfo- } \\
\text { gattömeg }\end{array}$ & \\
\hline $\begin{array}{l}\text { Többváltozós } \\
\text { lineáris regresszió } \\
\text { Görbebecslés }\end{array}$ & $\begin{array}{l}\text { TOMASELLA et } \\
\text { al. }(2000)\end{array}$ & $\begin{array}{l}0,002-0 ; 0,05-0,002 ; 0,2-0,05 \\
2-0,2 \text { mm-es szemcsefrakciók; } \\
\text { szerves szén; ,talajnedvességi } \\
\text { egyenérték”*; térfogattömeg }\end{array}$ & \\
\hline $\begin{array}{l}\text { Regressziós fa és } \\
\text { csoportos adat- } \\
\text { kezelés módszere }\end{array}$ & $\begin{array}{l}\text { RAWLS et al. } \\
(2003)\end{array}$ & $\begin{array}{l}\text { fizikai féleség, szerves szén, } \\
\text { talajtípus }\end{array}$ & $\mathrm{pF} 2,5 ; \mathrm{pF} 4,2$ \\
\hline $\begin{array}{l}\text { Többváltozós lineá- } \\
\text { ris és nem-lineáris } \\
\text { regresszió } \\
\text { Görbebecslés }\end{array}$ & $\begin{array}{l}\text { RAJKAI et al. } \\
(2004)\end{array}$ & $\begin{array}{l}0,002-0 ; 0,05-0,002 ; 2-0,05 \\
\text { mm-es szemcsefrakciók; szer- } \\
\text { ves anyag; térfogattömeg; } \\
\text { szabadföldi vízkapacitás }\end{array}$ & $\begin{array}{l}\text { van Genuchten- } \\
\text { függvény három } \\
\text { paramétere: } \\
\Theta_{\mathrm{s}}, \alpha, \mathrm{n}\end{array}$ \\
\hline
\end{tabular}

Megjegyzés: *A TOMASELla és munkatársai (2000) által használt „talajnedvességi egyenérték” fogalom (moisture equivalent) azt a nedvességtartalmat jelenti, ami 2400 fordulat/perc-es 30 percig tartó centrifugázás után marad a talajban. Nem egyezik meg a BRIGGS és MCLANE (1907) által használt „talajnedvességi egyenérték” fogalommal

Néhány modell becslési pontosságát (accuracy of estimation) WÖSTEN és munkatársai (2001) táblázatba foglalva mutatja be.

A ptf/ptr-ek fejlesztésében a pontosság és a megbízhatóság (reliability of estimation) vizsgálatára többek között a következő statisztikai elemzéseket használják (WÖSTEN et al., 2001): korrelációs koefficiens, determinációs együttható, F-próba; átlagos abszolút hiba, relatív hiba vagy t-próba.

A görbebecslés hibaszámítását RAJKAI (2004) a pF-görbére vonatkozó átlagos hiba meghatározásával végezte, a következő egyenlettel: 


$$
Z A P F=\frac{\sum_{i=1}^{n}\left|\Theta_{e}-\Theta_{m}\right|}{n}
$$

ahol: n: a víztartóképesség-függvényt meghatározó illesztési pontok száma; $\Theta_{\mathrm{e}}$ : a becsült nedvességtartalom (\%); $\Theta_{\mathrm{m}}$ : a mért nedvességtartalom (\%).

RAJKAI (2004) jónak tekintette azt a víztartóképesség-becslést, amikor $|\mathrm{ZAPF}|<2,5$. A ZAPF ezen értéke a víztartó képesség méréssel történő meghatározásának átlagos hibájával megegyező.

Amennyiben több víztartóképesség-becslő modell is a rendelkezésünkre áll, a kiválasztásnál a becslés hibájának figyelembe vétele mellett, a becsléshez szükséges paraméterszámra is figyelemmel kell lenni. Az F-próba alkalmazásával a kisebb hibájú modellt választhatjuk ki. Több, különböző paraméterszámú modell esetén, a modelljóság megállapítására kidolgozott kritériumok mérlegelésével dönthető el, hogy melyik a legalkalmasabb modell. RAJKAI (2004) és RUSSO (1988, cit: WÖSTEN et al., 2001) a pFadatokra illesztett egyenlet és a különböző paraméterszámú becslő modellel kapott pFgörbék összehasonlítására az Akaike-féle információs kritériumot (AIC) használta:

$$
A I C=N \cdot \ln \left(\frac{S S Q}{N}\right)+2 \cdot P
$$

ahol: N: a mintaelemszám; SSQ: a hibanégyzet összeg; $\mathrm{DF}_{\text {hiba: }}$ a hiba szabadságfoka; $\mathrm{P}$ : a modell paraméterszáma.

Az Akaike kritérium alapján a kisebb AIC értékü a megfelelőbb modell. A modellválasztási kritériumok közül ennek a kritériumnak a használata a legelterjedtebb.

A pF-becslő eljárás jellemzésére használjuk a becslési hatékonyság (RAJKAI, 2004) mutatót, amely a vizsgált adatbázisra százalékosan fejezi ki a jó, vagyis a 2,5\%-nál kisebb átlagos hibájú (MAE) becslések számát.

\section{Talajfizikai tulajdonságok becslésére szolgáló szoftverek}

A becslő módszerek közül sokat számítógépes algoritmusba is beépítettek, megkönnyítve ezzel a pedotranszfer függvények gyakorlati alkalmazását. Ilyen program például a $k$-Nearest (NEMES et al., 2008), a TALAJTANonc 1.0 (FODOR \& RAJKAI, 2005), a Neuro Multistep (MINASNY et al., 2004), a SOILPAR 2.0 (ACUTIS \& DONATELLI, 2003), a MUUF (Map Unit User File) (RAWLS et al., 2001), a ROSETTA (SCHAAP et al., 2001), vagy az SH-Pro (CRESSWELL et al., 2000). Ezek a programok általában több becslö függvényt is tartalmaznak, a felhasználónak kell eldöntenie, hogy számára melyik a legalkalmasabb. A jövőben olyan automatizált döntéstámogató rendszereket (soil inference systems) szándékoznak kifejleszteni, amelyek a bevitt adatok és a becsülni kívánt talajtulajdonság alapján kiválasztják a legalkalmasabb - legkisebb hibával becslő - pedotranszfer függvényeket. Ezek a döntéstámogató rendszerek nemcsak talaj vízgazdálkodási, de egyéb talajfizikai és -kémiai tulajdonságok becslésére is használhatók (MCBRATNEY et al., 2002).

A TALAJTANonc 1.0 hazai fejlesztésű program, amely hazai és külföldi fejlesztésű talajfizikai becslési eljárásokat tartalmaz. A program víztartóképesség-, vízvezetőképes- 
ség-függvényt számít, valamint további 11 algoritmust tartalmaz, melyek segítségével a könnyebben mérhető talajtulajdonságokból talajfizikai és vízgazdálkodási jellemzők becsülhetök (FODOR \& RAJKAI, 2005). Ez a program alkalmas keretet biztosíthat a későbbiekben kidolgozandó ptf-ek számítógépes alkalmazására is.

\section{A becslő módszerek alkalmazása}

A pedotranszfer függvények becslési eredményeit legtöbbször modellezésben használják, mint például a talaj vízmozgás modellezése (FODOR \& RAJKAI, 2004), vagy annak területi jellemzése (BAKACSI et al., 2008). Az említetteken kívül a becsült talajjellemzőknek még nagyon sokféle alkalmazási lehetősége van. Néhány példa a felhasználási lehetőségek közül: a talaj vízforgalmának leírása a növénytermesztési modellekben (FODOR \& KOVÁCS, 2001; FODOR et al., 2001), a talajerózió modellezése (PACHEPSKY \& RAWLS, 2004), a talajok klímaérzékenységének vizsgálata (FARKAS et al., 2009), a szén- és nitrogén körforgalmának modellezése (LI et al., 2007), a földminősítés (MAKÓ et al., 2007), a termésbecslés talajtani paramétereinek megalapozása Európában (BARUTH et al., 2008), vagy a peszticid- és a nitrátkimosódás elemzése (MCBRATNEY et al., 2002).

A dolgozat az OTKA 62436 és T048302 számú kutatási pályázatok támogatásával készült.

\section{Irodalom}

Acutis, M. \& Donatelli, M., 2003. SOILPAR 2.00: Software to estimate soil hydrological parameters and functions. European J. Agron. 18. (3-4) 373-377.

AhUJA, L. R., NANEY, J. W. \& Williams, R. D., 1985. Estimating soil water characteristics from simpler properties or limited data. Soil Sci. Soc. Am. J. 49. 1100-1105.

Al Majou, H. et al., 2008. Prediction of soil water retention properties after stratification by combining texture, bulk density and the type of horizon. Soil Use and Man. 24. (4) 383-391.

ARYA, L. A. \& PARIS, J. F., 1981. A physico-empirical model to predict the moisture characteristics from particle-size distribution and bulk density data. Soil Sci. Soc. Am. J. 45. 1023-1030.

BAKACSI Zs. et al., 2008. Talajhidrológiai paraméterek regionalizálása a Bodrogközben. In: Talajtani Vádorgyülés, Nyíregyháza, 2008. május 28-29. 33-42. Talajvédelmi Alapítvány Bessenyi György Könyvkiadó.

BAKER, L., 2008. Development of class pedotransfer functions of soil water retention - A refinement. Geoderma. 144. 225-230.

BAKER, L. \& ELLISON, D., 2008. Optimisation of pedotransfer functions using an artificial neural network ensemble method. Geoderma. 144. 212-224.

BARUTH, B. et al., 2008. The use of remote sensing within the MARS Crop Yield Monitoring System of the European Commission. In: The International Archives of the Photogrammetry, Remote Sensing and Spatial Information Sciences. 37. Part B8. 935-940.

BASTET, G., 1999. Estimation des propriétés de rétention en eau des sols à l'aide de fonctions de pédotransfert: développement de nouvelles approches. Thès de Doctorat de l'Université d'Orléans, France. Cit: PAChePsKy, Y. A. \& RAwls, W. J. (Eds.), 2004. Development of Pedotransfer Functions in Soil Hydrology. Chapter 10. Developments in Soil Science. Elsevier. Amsterdam.

BATJES, N. H., 1996. Development of a world data set of soil water retention properties using pedotransfer rules. Geoderma. 71. 31-52. 
BAtJES, N. H. et al., 1997. Soil data derived from WISE for use in global and regional AEZ studies (ver.1.0). Interim Report IR-97-025. Laxenburg, FAO/IIASA/ISRIC: 27.

BAtJes, N. H. et al., 2007. Preparation of consistent soil data sets for modelling purposes: Secondary SOTER data for four case study areas. Agric., Ecosyst. Environ. 122. 26-34.

Bell, M. A. \& van Keulen, J., 1995. Soil pedotransfer functions for four Mexican soils. Soil Sci Soc. Am. J. 59. 865-871. cit: MinASNY, B., 2007. Predicting soil properties. Jurnal Ilmu Tanah dan Lingkungan. 7. (1) 54-67.

Børgesen, C. D. \& SCHAAP, M. G., 2005. Point and parameter pedotransfer functions for water retention predictions for Danish soils. Geoderma. 127. 154-167.

BoumA, J., 1989. Using soil survey data for quantitative land evaluation. Advances in Soil Science. 9. 177-213.

Bouma, J. \& VAN LANEN, H. A. J., 1987. Transfer functions and threshold values: from soil characteristics to land qualities. In: Quantified Land Evaluation Procedures, Proc. Internat. Workshop on Quantified Land Evaluation Procedures, Washington, D. C., 27 April-2 May 1986. 106-110. ITC. Publ. Enschende, The Netherlands.

BRIGGS, L. J. \& MCLANE, J. W., 1907. The moisture equivalent of soils. USDA Bureau of Soils. Bulletin. 45. 5-23.

Brooks, R. H. \& Corey, A. T., 1964. Hydraulic Properties of Porous Media. Hydrological Paper No. 27. Colorado State University. Fort Collins.

Bruand, A., PÉrez Fernandez, P. \& Duval, O., 2003. Use of class pedotransfer functions based on texture and bulk density of clods to generate water retention curves. Soil Use and Management. 19. (3) 232-242.

BRUTSAERT, W., 1966. Probability laws for pore size distributions. Soil Sci. 117. 311-314.

Comegna, V., Damiani, P. \& Somella, A., 1998. Use of a fractal model for determining soil water retention curves. Geoderma. 85. 307-323.

ConNelis, W. M. et al., 2001. Evaluation of pedotransfer functions for predicting the soil moisture retention curve. Soil Sci. Soc. Am. J. 65. 638-648.

Cresswell, H. P. et al., 2000. The SH-Pro V1.03 Software for Predicting and Analysing Soil Hydraulic Properties. CSIRO Land and Water. Canberra, Australia.

DARoussin, J. \& KING, D., 1996. Pedotransfer rules database to interpret the Soil Geographical Database of Europe for environmental purposes. In: Proc. Workshop "Use of Pedotransfer in Soil Hydrology Research in Europe", Orleans, France, 10-12 October 1996. 25-40.

FARKAS Cs. et al., 2009. A talajvízmérleg klímaérzékenységének vizsgálata mészlepedékes csernozjom talajokon. Agrokémia és Talajtan. 58. 197-212.

FodOR N. \& KovÁCS G. J., 2001. A CERES modell továbbfejlesztése. II. A Richards-egyenlet paramétereinek meghatározása méréssel, ill. pedotranszfer függvények segítségével. Agrokémia és Talajtan. 50. 47-61.

Fodor N., KovÁcs G. J. \& KARUCZKA A., 2001. A CERES modell továbbfejlesztése. I. A Richards-egyenlet beépítése után, összehasonlítás az eredeti változattal. Agrokémia és Talajtan. 50. 35-47.

FODOR N. \& RAJKAI K., 2004. Talajfizikai tulajdonságok becslése és alkalmazásuk modellekben. Agrokémia és Talajtan. 53. 225-238.

FODOR N. \& RAJKAI K., 2005. Számítógépes program a talajok fizikai és vízgazdálkodási jellemzőinek egyéb talajjellemzőkből történő számítására (TALAJTANonc 1.0). Agrokémia és Talajtan. 54. 25-40.

GiMĖNEZ, D. et al., 2001. Prediction of a pore distribution factor from soil textural and mechanical parameters. Soil Sci. 166. 79-88.

GUPTA, S. C. \& LARSON, W. E., 1979. Estimating soil water retention characteristics from particle size distribution, organic matter percent, bulk density. Water Resources Research. 15. 16331635.

Hall, D. G. et al., V. F., 1977. Water Retention, Porosity and Density of Field Soils. Technical Monograph. No. 9. Soil Survey of England and Wales. Harpenden. 
Haverkamp, R. \& Parlange, J. Y., 1986. Predicting the water-retention curve from particle-size distribution: 1. Sandy soil without organic matter. Soil Sci. 142. 325-339.

IDEN, S. C. \& DuRNER, W., 2008. Free-form estimation of soil hydraulic properties using Wind's method. European J. Soil Sci. 59. 1228-1240.

JAMAGNE, M. et al., 1977. Quelques données sur la variabilité dans le milieu naturel de la réserve en eau des sols. Bull. Information Tech. 324-325, 627-641. cit: PACHEPSKY, Y. A. \& RAWLS, W. J. (Eds.), 2004. Development of Pedotransfer Functions in Soil Hydrology. Chapter 10. Developments in Soil Science. Elsevier. Amsterdam.

KotzmanN L., 1938. A higroszkópos nedvesség, mint a talaj kötöttségének jellemzője. Mezőgazd. Kutatások. 11. 217. cit: MADOS (KoTZMANN) L., 1939. Öntözési és vízgazdálkodási tanulmányok a tiszafüredi öntözőrendszer területén. Öntözésügyi Közlem. 1. (1) 89-116.

KREYBIG L., 1951. A talajok hö- és vízgazdálkodása. Mezőgazdasági Kiadó. Budapest.

LAMP, J. \& KNEIB, W., 1981. Zur quantitativen Erfassung und Bewertung von Pedofunktionen. Mitteilungen der Deutschen Bodenkundlichen Gesellschaft. 32. 695-711.

LI, Y. et al., 2007. Estimating soil hydraulic properties of Fengqiu County soils in the North China Plain using pedotransfer functions. Geoderma. 138. 261-271.

Lilly, A., Boorman, D. B. \& Hollis, J. M., 1996 The use of pedotransfer in the development of a hydrological classification of UK soils (HOST). Proc. Workshop "Use of Pedotransfer in Soil Hydrology Research in Europe", Orleans, France, 10-12 October 1996. 55-57.

LIN, H. S. et al., 1999. Effects of soil morphology on hydraulic properties: II. Hydraulic pedotransfer functions. Soil Sci. Soc. Am. J. 63. 955-961.

Mados (KotZmanN) L., 1939. Öntözési és vízgazdálkodási tanulmányok a tiszafüredi öntözörendszer területén. Öntözésügyi Közlemények. 1. (1) 89-116.

Mados L., 1942. Általános talajtani ismeretek. Kézirat. Diószegi Lehel Leíró- és Sokszorosító Irodája. Budapest.

MAKÓ, A., 2002. Measuring and estimating the pressure-saturation curves on undisturbed soil samples using water and NAPL. Agrokémia és Talajtan. 51. 27-36.

MAкó A. \& TóTH B., 2007. A talajok vízgazdálkodása és a talajtermékenység. Agronapló. XI. 2007/02.

MAKÓ A., TóTH B. \& RAJKAI K., 2007. A talajok vízgazdálkodási tulajdonságainak földminősítési célú becslése. In: Földminősítés a XXI. században! Földminőség, földértékelés és földhasználati információ a környezetbarát gazdálkodás versenyképességének javításáért. Keszthely, 2007. november 22-23. 45-50. MTA Talajtani és Agrokémiai Kutatóintézet. Budapest.

MAKÓ, A. et al., 2005. Estimating soil water retention characteristics from the soil taxonomic classification and mapping informations: consideration of humus categories. Cereal Res. Commun. 34. 199-201.

MAKó, A. et al., 2010a. Introduction of the Hungarian Detailed Soil Hydrophysical Database (MARTHA) and its use to test external pedotransfer functions. Agrokémia és Talajtan. 59. 29-38.

MAKÓ A. et al., 2010b. A MARTHA adatbázis alkalmazása a hazai talajok víztartó képesség becslésének pontosítására. Talajvédelem. (Megjelenés alatt)

MAYR, T. \& JARVIS, N. J., 1999. Pedotransfer functions to estimate soil water retention parameters for a modified Brooks-Corey type model. Geoderma. 91. 1-9.

MCBRATNEY, A. B. et al., 2002. From pedotransfer functions to soil inference systems. Geoderma 109. 41-73.

McKenZie, N. J. \& MACLEOD, D. A., 1989. Relationships between soil morphology and soil properties relevant to irrigated and dryland agriculture. Aust. J. Soil Res. 35. 803-825.

MinASNY, B. 2007. Predicting soil properties. Jurnal Ilmu Tanah dan Lingkungan. 7. (1.) 54-67.

Minasny, B., McBratney, A. B. \& Bristow, K. L., 1999. Comparison of different approaches to the development of pedotransfer functions for water-retention curves. Geoderma. 93. 225253. 
MinASNY, B. et al., 2004. Neural networks prediction of soil hydraulic functions for alluvial soils using multistep outflow data. Soil Sci. Soc. Am. J. 68. 417-429.

Nemes, A., 2002. Unsaturated Soil Hydraulic Database of Hungary: HUNSODA. Agrokémia és Talajtan. 51. 17-26.

Nemes, A., SchaAp, M. G. \& Wösten, J. H. M., 2003. Functional evaluation of pedotransfer functions derived from different scales of data collection. Soil Sci. Soc. Am J. 67. 1093-1102.

NEMES, A. et al., 1999. Evaluation of different procedures to interpolate particle-size distributions to achieve compatibility within soil databases. Geoderma. 90. 187-202.

NEMES, A. et al., 2001. Description of the unsaturated soil hydraulic database UNSODA version 2.0. J. Hydrol. 251. 151-162.

Nemes, A. et al., 2008. Software to estimate -33 and $-1500 \mathrm{kPa}$ soil water retention using the nonparametric k-nearest neighbor technique. Environ. Modelling \& Software. 23. (2) 254-255.

PACHEPSKY, Y. A. \& RAWLS, W. J., 2003. Soil structure and pedotransfer functions. European J. Soil Sci. 54. 443-451.

PachePsky, Y. A. \& Rawls, W. J. (Eds.), 2004. Development of Pedotransfer Functions in Soil Hydrology. Developments in Soil Science. Elsevier. Amsterdam.

PACHEPSKY, Y. A., RAWLS, W. J. \& LiN, H. S., 2006. Hydropedology and pedotransfer functions. Geoderma. 131. 308-316.

Pachepsky, Y. A., Timlin, D. J. \& Rawls, W. J., 2001. Soil water retention as related to topographic variables. Soil Sci. Soc. Am. J. 65. 1787-1795.

PachePsky, Y. A., Timlin, D. \& VÁrallyay, Gy., 1996. Artificial neural networks to estimate soil water retention from easily measurable data. Soil Sci. Soc. Am. J. 60. 727-733.

PACHEPSKY, YA.A. et al., 1982. Soil water retention as related to other soil physical properties. Pochvovedenie. 2. 42-52.

QUISENBERRY, V. L. et al., 1993. A soil classification system for describing water and chemical transport. Soil Sci. 156. 306-315.

RAJKAI K., 1988. A talaj víztartó képessége és különböző talajtulajdonságok összefüggésének vizsgálata. Agrokémia és Talajtan. 36-37. 15-30.

RAJKAI K., 2004. A víz mennyisége, eloszlása és áramlása a talajban. MTA TAKI. Budapest.

RAJKAI K. \& KABOS S., 1999. A talaj víztartóképesség-függvény (pF-görbe) talajtulajdonságok alapján történő becslésének továbbfejlesztése. Agrokémia és Talajtan. 48. 15-32.

RAJKAI, K. \& VÁRALLYAY, GY., 1992. Estimating soil water retention from simpler properties by regression techniques. In: Proc. Internat. Workshop on Indirect Methods for Estimating the Hydraulic Properties of Unsaturated Soils. 417-426. University of California, Riverside, CA.

Rajkai, K., Kabos, S. \& VAN Genuchten, M. T., 2004. Estimating the water retention curve from soil properties: Comparison of linear, nonlinear and concomitant variable methods. Soil and Tillage Research. 79. (2 Spec. issue) 145-152.

RAJKAI K. et al., 1981. pF-görbék számítása a talaj mechanikai összetétele és térfogattömege alapján. Agrokémia és Talajtan. 30. 409-438.

RAWLS, W. J., 1983 Estimating soil bulk density from particle size analysis and organic matter content. Soil Sci. 135. 123-125.

RAWLS, W. J. \& BRAKENSIEK, D. L., 1982. Estimating soil water retention from soil properties J. Irrig. Drainage Div. ASCE. 108. 166-171.

Rawls, W. J. \& BraKensieK, D. L., 1985. Prediction of soil water properties for hydrologic modeling. In: Watershed Management in the 1980s. Proc. Symposium of Irrig. Drainage Div., Denver, CO., April 30-May 1, 1985. 293-299. Am. Soc. Civil Eng., New York.

Rawls, W. J., BrakensieK, C. L. \& SAXton, K. E., 1982. Estimation of soil water properties. Transactions American Society of Agricultural Engineers. 25. 1316-1320.

Rawls, W. J., BrakensieK, D. L. \& Soni, B., 1983. Agricultural management effects on soil water processes. Part I. Soil water retention and Green-Ampt parameters. Transactions American Society of Agricultural Engineers. 26. 1747-1752. 
Rawls, W. J., Nemes, A. \& Pachepsky, Y. A., 2004. Effect of soil organic carbon on soil hydraulic properties. In: Developments in Soil Science. 30. 95-114. Elsevier. Amsterdam.

Rawls, W. J., Pachepsky, Y. A. \& Shen, M. H., 2001. Testing soil water retention estimation with the MUUF pedotransfer model using data from the southern United States. Journal of Hydrology. 251. 177-185.

RAwLS, W. J. et al., 2003. Effect of soil organic carbon on soil water retention. Geoderma. 116. $61-76$.

Romano, N. \& Palladino, M., 2002. Prediction of soil water retention using soil physical data and terrain attributes. Journal of Hydrology. 265. 56-75.

Rossiter, D. G., 2003. Biophysical models in land evaluation. In: Encyclopedia of Life Support Systems (EOLSS), developed under the auspices of the UNESCO. (Ed.: VERHEYE, W. H.) Article 1.5.27. in Theme 1.5 Land Use and Land Cover. 1-16. EOLSS Publishers. Oxford.

Russo, D., 1988. Determining soil hydraulic properties by parameter estimation, on the selection of a model for the hydraulic properties. Water Resour. Res. 24. 453-459. In: WÖSTEN, J. H. M., PAChepsky, Y. A. \& RAWLS, W. J., 2001. Pedotransfer functions: bridging the gap between available basic soil data and missing soil hydraulic characteristics. Journal of Hydrology. 251. (3-4) 123-150.

SAlter, P. J. \& Williams, J. B., 1965. The influence of texture on the moisture characteristics of soils. I. A critical comparison for determining the available water capacity and moisture characteristics curve of a soil. J. Soil Sci. 16. 1-15.

Salter, P. J. \& Williams, J. B., 1967. The influence of texture on the moisture characteristics of soils. IV. A method of estimating the available-water capacities of profiles in the field. J. Soil Sci. 18. 174-181.

SANTRA, P. \& DAS, B. S., 2008. Pedotransfer functions for soil hydraulic properties developed from a hilly watershed of Eastern India. Geoderma. 146. 439-448.

SÁRKÖZY F., 1998. Mesterséges neurális hálózatok mint GIS függvények. In: Geomatika a geodézia elméletében és gyakorlatában, Sopron, 1998. október 29-30. Geom. Közlem. I. 109-129.

SCHAAP, M. G. \& LEIJ, F. J., 1998. Database-related accuracy and uncertainty of pedotransfer functions. Soil Sci. 163. 765-779.

SchAAP, M. G., LeiJ, F. J. \& VAN GenUChten, M. T., 1999. A bootstrap-neural network approach to predict soil hydraulic parameters. In: Proc. Internat. Workshop Characterization and Measurements of the Hydraulic Properties of Unsaturated Porous Media. 1237-1250.

SchaAP, M. G., LeiJ, F. J. \& VAn Genuchten, M. T., 2001. Rosetta: A computer program for estimating soil hydraulic parameters with hierarchical pedotransfer functions. Journal of Hydrology. 251. 163-176.

ScheinOst, A. C., SinOwSKi, W. \& Auerswald, K., 1997. Regionalization of soil water retention curves in a highly variable soilscape. I. Developing a new pedotransfer function. Geoderma. 78. 129-143.

SHARMA, S. K., MOHANTY, B. P. \& ZhU, J., 2006. Including topography and vegetation attributes for developing pedotransfer functions. Soil Sci. Soc. Am. J. 70. 1430-1440.

Stefanovits P., Filep Gy. \& Füleky Gy., 1999. Talajtan. Mezőgazda Kiadó Budapest.

Tempel, P., Batjes, N. H. \& van Engelen, V. W. P., 1996. IGBP-DiS Soil Data Set for Pedotransfer Function Development. Working paper and Preprint 96/05, ISRIC. Wageningen.

TieTJe, O. \& TAPKenhinRichS, M., 1993. Evaluation of pedo-transfer functions. Soil. Sci. Soc. Am. J. 57. 1088-1095.

Tomasella, J., Hodnett, M. G., Rossato, L., 2000. Pedotransfer functions for the estimation of soil water retention in Brazilian soils. Soil Sci. Soc. Am. J. 64. 327-338.

Tomasella, J. et al., 2003. Comparison of two techniques to develop pedotransfer functions for water retention. Soil Sci. Soc. Am. J. 67. 1085-1092.

То́тн В. et al., 2005. A talajok víztartóképességének becslési lehetőségei genetikus üzemi talajtérképek és kartogramok alapján. III. Erdei Ferenc Konferencia, Kecskemét 2005. augusztus 23-24. 850-854. 
То́тн, B. et al., 2006. Use of soil water retention capacity and hydraulic conductivity estimation in the preparation of soil water management maps. Agrokémia és Talajtan. 55. 49-58.

Tranter, G, McBratney, A. B. \& Minasny, B., 2009. Using distance metrics to determine the appropriate domain of pedotransfer function predictions. Geoderma. 149. 421-425.

Tyler, S. W. \& WheAtcraft, S. W., 1989. Application of fractal mathematics to soil water retention estimation. Soil Sci. Soc. Am. J. 53. 987-996.

UnO,Y. et al., 2005 Development of field-scale soil organic matter content estimation models in Eastern Canada using airborne hyperspectral imagery. Canadian Biosystems Engineering. 47. $1.9-1.14$.

VAN GenuChten, M. Th., 1980. Closed-form equation for predicting the hydraulic conductivity of unsaturated soils. Soil Sci. Soc. Am. J. 44. 892-898.

VÁRALLYAY GY., 2002. A mezőgazdasági vízgazdálkodás talajtani alapjai. Budapest.

VÁRALLYAY GY., 2004. A talaj vízgazdálkodásának agroökológiai vonatkozásai. AGRO-21 Füzetek. 37. 50-70.

VÁRALLYAY GY., 2005a. Magyarország talajainak vízraktározó képessége. Agrokémia és Talajtan. 54. 5-24.

VÁRALlyay Gy., 2005b. Soil water management and the environment. In: Environmental Science and Technology in Hungary. Müszaki Kiadó. Budapest. CD ROM.

VÁrallyay Gy. et al., 1979. A pF-görbék matematikai leírása. Agrokémia és Talajtan. 28. 1538.

ID. VÁRALlyay Gy., 1942 Öntözési tapasztalatok Márialigeten. Öntözésügyi Közlemények. 4. (2) 323-325.

VEREECKEN, H. et al., 1989. Estimating the soil moisture retention characteristics from texture, bulk density and carbon content. Soil Sci. 148. 389-403.

WALCZAK, R. T. et al., 2006. Modeling of soil water retention curve using soil solid phase parameters. Journal of Hydrology. 329. 527-533.

Wösten, J. H. M., FinKe, P. A. \& JANSEN, M. J. W., 1995. Comparison of class and continuous pedotransfer functions to generate soil hydraulic charactristics. Geoderma. 66. 227-237.

Wösten, J. H. M., PAChePsky, Y. A. \& RAWLS, W. J., 2001. Pedotransfer functions: bridging the gap between available basic soil data and missing soil hydraulic characteristics. Journal of Hydrology. 251. 123-150.

WÖSTEN, J. H. M. et al., 1990. Functional sensivity analysis of four methods to generate soil hydraulic functions. Soil Sci. Soc. Am. J. 54. 832-836.

WÖsten, J. H. M. et al., 1999. Development and use of a database of hydraulic properties of European soils. Geoderma. 90. 169-185.

Érkezett: 2010. augusztus 2.

TÓTH BRIGITTA

Pannon Egyetem, Georgikon Kar,

Keszthely

Postai cím: TÓTH BRIGITTA, Pannon Egyetem, Georgikon Kar, 8360 Keszthely, Deák F. u. 16.

E-mail: gema@freemail.hu 